\title{
Overestimation and Venture Survival: An empirical Analysis of Development Commitments in
}

\section{InTERnAtional Master FRANCHISING Ventures}

\author{
ARTURS KALNINS ${ }^{1}$ \\ Cornell University
}

Many international master franchising contracts include "development commitments," clauses specifying a number of units that master franchisees must develop in exchange for exclusive rights to an assigned market, typically their entire home nation. I analyze 142 contracts with development commitments signed by US fast food franchisors and their master franchisees. Several empirical regularities emerge from the analysis: First, the development commitments are large and rarely completely fulfilled. Second, a robust negative relationship exists between survival and development commitment size. Further, ventures with larger commitments exhibit a lower level of investment still productive at the end of the development period. Various explanations for these regularities are considered.

\section{INTRODUCTION}

Master franchising has become the most popular governance form for US franchisors in foreign markets (Zietlow and Hennart, 1996). Most international master franchising contracts contain a development commitment. Franchisors use this clause to specify a number of units (restaurants, hotels, etc.) to be developed by the master franchisee in its territory within a certain time period.

In this paper, I explore two related questions. First, why development commitments of US fast food franchisors tend to be so large relative to the actual number of units that survive. In my sample of 142 international master franchising contracts, the median development commitment size is 34 units or $\$ 19.2$ million when normalized across chains by average investment per unit for each franchisor's brand. There is substantial within-country and within-franchisor variation in commitment size. The commitments for Japan range from 20 to 2,000 units ( $\$ 5$ million to $\$ 300$ million), for example, while those involving Domino's Pizza range from 3 to 400 units ( $\$ 450,000$ to $\$ 60$ million). Yet, among 55 of 142 ventures that still exist at the end of their development periods, a median of only three units operates at that time. Franchisees fulfilled or exceeded the development commitment in only 6 of the 142 ventures.

The second question I investigate is why the initial development commitment size appears negatively related to important venture- level outcomes. I estimate regressions showing that larger development commitments are associated with (1) a lower probability of venture survival, (2) a lower level of investment still productive at the end of the development commitment period (number of units still in operation normalized by average investment per unit for each franchisor's brand), and (3) a smaller proportion of the initial commitment operating at the end of the development period. Although the data available cannot provide definitive answers, I evaluate the plausibility of several competing explanations: systematic overestimation of market potential by franchisors and franchisees, a rational risk-return trade-off, quality signaling, and strategic preemption.

The remainder of the paper is organized as follows. In Section 2, I describe international master franchising ventures and development commitments. Section 3 discusses methods and variables, while Section 4 presents the results of statistical analyses. Section 5 discusses potential explanations for the patterns found in the data. Section 6 concludes.

\section{Master franchising Contracts and Development Commitments 2.1. International Master franchising CONTRACtS}

Under master franchising contracts, franchisors assign entire territories to franchisees for exclusive development. Some contracts specify that the master franchisee must operate all the units within their territory. These are also called area development agreements. Other contracts allow the master franchisees to subfranchise to others. Master franchising is the most common entry mode of US franchisors in foreign markets. Zietlow and Hennart (1996) found that, among 35 food franchisors, master franchising was used for 227 (68\%) of 333 foreign market entries. Of these 227,164 were subfranchising contracts and 63 were area development agreements. Walker (1989) reported that master franchising is particularly popular for foreign entry. He surveyed 152 franchisors and found that $50 \%$ use subfranchising contracts internationally compared to only $15 \%$ domestically.

In 122 of the 142 ventures examined in this study, franchisees were native to the territory assigned them, while 12 were based in the United States. Among the remaining eight, Israeli franchisees operated ventures in the Netherlands and the Phillipines, a Canadian franchisee operated in Poland, and a Cypriot franchisee in Saudi Arabia. Ten franchisees had previous experience with a different US franchisor in their native country and four with the same franchisor in a different country.

\subsection{Terms and Fees of international master franchising Contracts}

Like domestic franchisees, international master franchisees pay the franchisor an upfront fee plus an ongoing royalty, typically from $2 \%$ to $8 \%$ of gross sales. The master franchisees pay promotional expenses for their home nation. If the master franchisees own the units themselves, they pay all operating expenses and, in some cases, an additional fee per unit opened. They keep any residual profit. If they subfranchise, they receive a sales royalty from the final franchisees. Although the sales royalty rates for international franchising often are identical to domestic rates (e.g., Lafontaine and Oxley, 2004), the upfront fees for exclusive country rights are typically larger. Only 3 of the 142 announcements in my sample stated the country fee. In two contracts, it was $\$ 500,000$ and in the third it was $\$ 880,000$.

In return for such a fee, the franchisor grants the franchisee exclusive rights to one (or occasionally more than one) country. Exclusivity is a common feature in licensing and franchising contracts-Anand and Khanna (2000) report that some type of exclusivity clause is present in $37 \%$ of licensing contracts across a variety of industries. Exclusive territories provide a guarantee to franchisees that the franchisor will not sell licenses to others within their territory. For franchisees abroad, the exclusivity acts as an incentive to develop the franchisor's brand name, because the name often has little value in the host country before any units exist there.

A franchisee's exclusive rights typically end if the franchisee ceases operations. Yet, there are only three cases in my sample of 142 contracts where the same franchisor entered into a master franchising contract for the same country more than once sequentially with different franchisees. Subway and Arby's

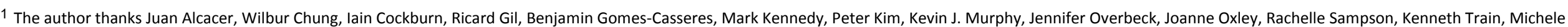

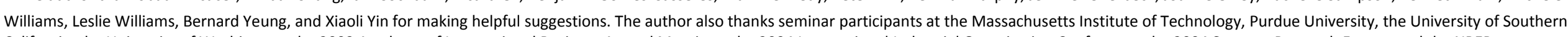
California, the University of Washington, the 2003 Academy of International Business Annual Meetings, the 2004 International Industrial Organization Conference, the 2004 Strategy Research Forum, and the NBER "Productivity Lunch" Seminar Series.
} 
entered Japan twice, while Pizza Inn entered Korea twice. In all three cases, the second development commitment was smaller than the first. Only Subway

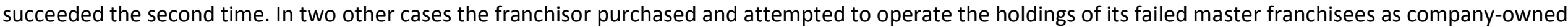
units. Neither of these ventures survived under any governance form.

\subsection{DeVelopment COMMitMents}

Development commitments range from a few units to thousands of them. Tables I and II show the size of the development commitments for the countries and franchisors, respectively, with the most contracts in the sample. The tables' right-hand side splits the contracts by commitment size, measured in millions of

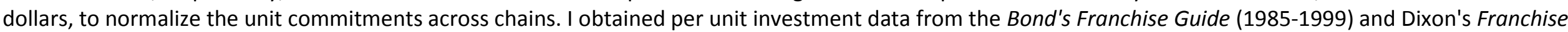
Annual (1987-1999). The per-unit investment ranged from a low of $\$ 90,000-\$ 100,000$ for sandwich shops such as Subway and Blimpie to $\$ 1.5$ million for fullservice restaurants such as Chili's and TGI Friday's.

In 84 of the 142 ventures, the contract announcement explicitly stated a development period within which the number of units specified in the commitment had to be built. The periods ranged from 3 to 10 years, with an outlier at 15 years. The median and mode ( 27 contracts) was 5 years and the mean was 5.91 years. Fifty-eight announcements did not state such periods.

Practitioner observers suggest that franchisors use large commitments to protect themselves against insufficient development of a market by the master franchisee (Estes, 1995; Bygrave, 1999, p. 384). Franchisors are likely to view as optimal a larger number of units than would the franchisees for at least three

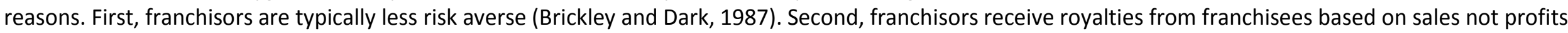
(Caves and Murphy, 1976; Kaufmann and Rangan, 1990), causing a doublemarginalization problem. Third, franchisees may wish to develop similar "knock-off"

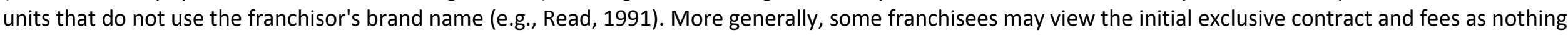
more than an option, a situation that franchisors can mitigate with a development commitment.

Consistent with the desire for full market development, franchisors have shown a preference for franchisees that agree to large development commitments. For example, Subway considered three bids for a Japanese master license and accepted the proposal with the largest commitment (Chaudhry,

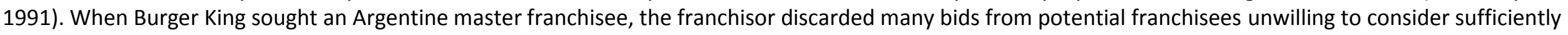
large commitments (Estes, 1995).

Few obvious franchisor or country characteristics explain any of the variation in development commitment size. Although not shown, I regressed

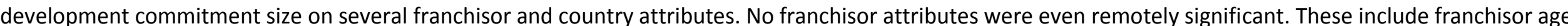
and size of domestic and international operations. Among country attributes, only country population had a significant effect. These independent variables are described in detail in Section 3.4

TABLE I.

Eleven Countries With THE MOst CONTRACTS IN THE SAMPLE

\begin{tabular}{|c|c|c|c|c|c|c|c|c|c|c|}
\hline \multirow[b]{2}{*}{ Country } & \multirow{2}{*}{\multicolumn{2}{|c|}{ Total Survivors }} & \multicolumn{4}{|c|}{$\begin{array}{l}\text { Size of Development } \\
\text { Commitments } \\
\text { (in \$ Millions) }\end{array}$} & \multicolumn{4}{|c|}{$\begin{array}{l}\text { Size of Development } \\
\text { Commitments } \\
\text { (in Units) }\end{array}$} \\
\hline & & & $\$ 0.45-\$$ & $10-\$$ & $20-\$$ & $\$ 40+$ & $3-2$ & $26-10$ & $101-2$ & $251+$ \\
\hline Japan & 19 & 3 & 1 & 6 & 5 & 7 & 2 & 8 & 4 & 5 \\
\hline $\begin{array}{l}\text { Saudi } \\
\text { Arabia }\end{array}$ & 10 & 7 & 2 & 2 & 3 & 3 & 6 & 3 & 1 & 0 \\
\hline $\begin{array}{l}\text { South } \\
\text { Korea }\end{array}$ & 8 & 3 & 2 & 2 & 3 & 1 & 4 & 2 & 2 & 0 \\
\hline Malaysia & 7 & 5 & 3 & 1 & 1 & 2 & 4 & 1 & 2 & 0 \\
\hline Mexico & 7 & 5 & 1 & 1 & 3 & 2 & 2 & 2 & 1 & 2 \\
\hline Thailand & 7 & 1 & 4 & 0 & 1 & 2 & 3 & 3 & 1 & 0 \\
\hline Australia & 6 & 1 & 0 & 1 & 2 & 3 & 2 & 2 & 2 & 0 \\
\hline Brazil & 6 & 1 & 2 & 1 & 1 & 2 & 0 & 5 & 1 & 0 \\
\hline Benelux & 5 & 3 & 2 & 2 & 1 & 0 & 5 & 0 & 0 & 0 \\
\hline Spain & 5 & 1 & 2 & 1 & 1 & 1 & 3 & 1 & 0 & 1 \\
\hline UK & 5 & 2 & 0 & 0 & 5 & 0 & 1 & 3 & 0 & 1 \\
\hline $\begin{array}{l}\text { Total of } \\
\text { Top } 11\end{array}$ & 85 & 32 & 19 & 17 & 26 & 23 & 32 & 30 & 14 & 9 \\
\hline Other 26 & 57 & 23 & 22 & 13 & 8 & 14 & 27 & 25 & 4 & 1 \\
\hline $\begin{array}{l}\text { Total of } \\
\text { Sample }\end{array}$ & 142 & 55 & 41 & 30 & 34 & 37 & 59 & 55 & 18 & 10 \\
\hline
\end{tabular}

\section{Data, Variables, ANd Methods}

\subsection{DATA SOURCES}

I collected the 142 contract announcements from press releases, newspaper articles, and trade journal articles in the Dow Jones News Retrieval 
TABLE II.

TWELVE FRANCHISORS WITH THE MOST CONTRACTS IN THE SAMPLE

\begin{tabular}{|c|c|c|c|c|c|c|c|c|c|c|}
\hline \multirow[b]{2}{*}{ Franchisor } & \multirow[b]{2}{*}{ Total } & \multirow[b]{2}{*}{ Survivors } & \multicolumn{4}{|c|}{$\begin{array}{l}\text { Size of Development } \\
\text { Commitments } \\
\text { (in \$ Millions) }\end{array}$} & \multicolumn{4}{|c|}{$\begin{array}{l}\text { Size of Development } \\
\text { Commitments } \\
\text { (in Units) }\end{array}$} \\
\hline & & & $\$ 0.45-\$ 10$ & $\$ 10-\$ 20$ & $\$ 20-\$ 40$ & $\$ 40+$ & $3-25$ & $26-100$ & $101-250$ & $251+$ \\
\hline Domino's & 12 & 8 & 5 & 4 & 2 & 1 & 4 & 4 & 3 & 1 \\
\hline Arby's & 9 & 2 & 2 & 1 & 4 & 0 & 3 & 6 & 0 & 0 \\
\hline Wendy's & 8 & 3 & 1 & 2 & 4 & 1 & 5 & 3 & 0 & 0 \\
\hline $\begin{array}{l}\text { TGI } \\
\text { Friday's }\end{array}$ & 7 & 6 & 2 & 2 & 2 & 1 & 6 & 1 & 0 & 0 \\
\hline $\begin{array}{l}\text { Burger } \\
\text { King }\end{array}$ & 6 & 5 & 0 & 2 & 1 & 3 & 2 & 4 & 0 & 0 \\
\hline Popeye's & 5 & 4 & 1 & 0 & 1 & 3 & 1 & 3 & 1 & 0 \\
\hline Chili's & 5 & 2 & 1 & 2 & 1 & 1 & 4 & 1 & 0 & 0 \\
\hline $\begin{array}{l}\text { Dunkin } \\
\text { Donuts }\end{array}$ & 5 & 2 & 5 & 0 & 0 & 0 & 4 & 1 & 0 & 0 \\
\hline Pizza Hut & 5 & 3 & 1 & 2 & 1 & 1 & 2 & 2 & 1 & 0 \\
\hline TCBY & 5 & 2 & 3 & 1 & 0 & 1 & 2 & 2 & 1 & 0 \\
\hline Cinnabon & 4 & 3 & 2 & 2 & 0 & 0 & 1 & 3 & 0 & 0 \\
\hline Pizza Inn & 4 & 0 & 0 & 0 & 3 & 1 & 0 & 4 & 0 & 0 \\
\hline $\begin{array}{l}\text { Total of } \\
\text { Top } 12\end{array}$ & 75 & 40 & 23 & 18 & 19 & 13 & 34 & 34 & 6 & 1 \\
\hline Other 40 & 67 & 15 & 18 & 12 & 15 & 24 & 25 & 20 & 13 & 9 \\
\hline Total & 142 & 55 & 41 & 30 & 34 & 37 & 59 & 54 & 19 & 10 \\
\hline
\end{tabular}

and the ASAP General Business File databases. These announcements, made between 1982 and 1999, all stated that franchisors and franchisees had settled on specific development commitments. I excluded from the data set 28 master franchising venture announcements that did not list the development commitment size and 10 joint venture announcements where the franchisor retained some equity. I also excluded all announcements where the end of the development commitment was later than 2004 to avoid any right-censoring.

This sample of 142 contract announcements appears to represent a substantial portion of all international master franchising activity in the fast food industry. The comprehensive Bond's Franchise Guide lists international units for 67 food-related US franchisors in 1998 , and the 35 internationally active food franchisors surveyed by Zietlow and Hennart (1996) listed a total of 227 master franchising agreements. The question remains why franchisors decided to

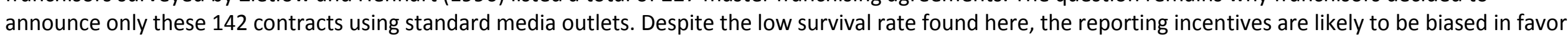
of survival. Franchisors should be likely to publicize those ventures they believe will survive, and not mention the initiation of those ventures most likely to exit.

\subsection{DEPENDENT VARIABLES}

I focus on three important venture-level outcomes: (1) whether the venture has survived until the end of the development period, or before the five-year

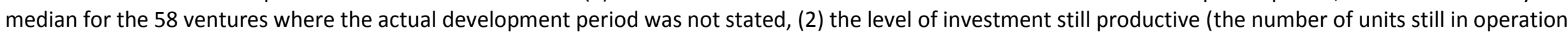

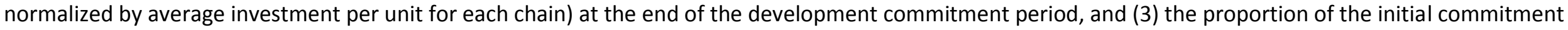

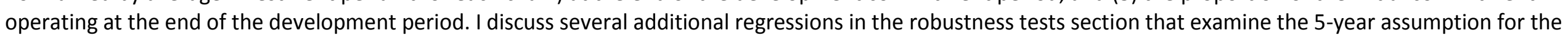
58 observations. The findings presented below are largely robust.

Venture survival is a coarse dependent variable, but if a venture does not survive until the end of the development period, its goal clearly has not been

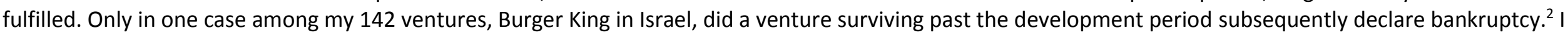

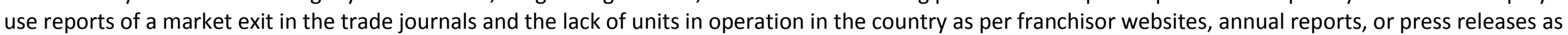
indicators that a venture did not survive. In Tables I and II, the second column shows the number of ventures still in operation at the end of the development

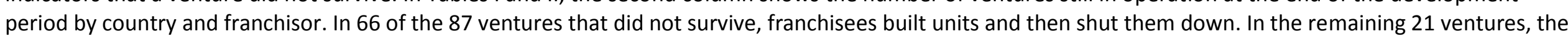
franchisees signed the contract and paid the fees, but never built any units.

\subsection{METHODS}

I analyze survival with a binary logit model. Chamberlain's logit model (Greene, 2000, p. 840) is used to ensure unbiased estimates in the presence of country and franchisor fixed effects. I use the multinomial logit model to analyze separately the venture exits where franchisees built units and shut them down and those where franchisees never actually built any units. The latter two dependent variables, ongoing productive investment in dollars and as a proportion of the development commitment, are analyzed with a tobit model because the 87 nonsurviving ventures are clustered at a value of zero.

\subsection{Independent Variables}

The main independent variable of interest is the development commitment size, as negotiated and reported in press releases before the initiation of the venture. Commitment sizes are normalized to US dollars, based on the investment per unit for each franchisor's brand. Three franchisor attributes are included as controls. These are the size of US operations, the size of international operations, and number of years in business, all measured at the time each contract was signed. The operations variables are also normalized in US dollars. These variables potentially capture effects of franchisor reputation, quality, experience, and scale economies. Two additional franchisor characteristics are included: the number of years the franchisor firm operated their brand before taking on franchisees and the investment per unit required for the franchisor's brand. These variables were gathered from the Bond's Franchise Guide (1985-1999) and the Nation's Restaurant News "Top 50 International Chains" Issues (1990-1999). 
Some regressions include franchisor fixed effects to eliminate the possibility that unobservable static attributes of each franchisor might affect the coefficients of interest. These attributes include the quality of the franchisor's brand, minimum efficient scale requirements for the brand, any tendency of the franchisor to overestimate markets, or any tendency toward opportunism at the franchisees' expense.

There is little information about the franchisee in many of these contract announcements. I can only control for one franchisee char-acteristic in the regressions, namely "Experienced Franchisee." I set this variable to 1 if the franchisee company had previous foodservice experience or experience as a franchisee. About half of the franchisees are large conglomerates, most with a food service division. In 25 cases, announcements listed nothing more than names of individuals (15) or the term "investors" (10), along with some indication of nationality. These franchisees are treated as inexperienced.

To control for country level effects, I use each nation's GDP per capita and population in the year that the contract was signed, collected from the Euromonitor database, as well as country fixed effects in some regressions. I collected other country level variables more specific to the demand for and supply of fast food restaurants, but these were highly correlated with GDP. For example, Investext provides per capita spending at restaurants. This statistic was correlated 0.91 with GDP per capita.

Country fixed effects are included to eliminate the possibility that static attributes of each nation (e.g., legal regimes, cultural distance from the United States) are influencing the coefficients of interest. The fixed effects also eliminate any influence of country specific variations in minimum efficient scale requirements that could plausibly result in differences in desire for large development commitments.

Finally, I included a time trend to capture any potential industry- level learning effects. Descriptive statistics for all variables are presented in Table III.

\section{REgRESSION RESULTS}

\subsection{RESULtS Of LOGit ANALYSES}

Table IV contains the results of four logit regressions where the dependent variable is venture survival. The first column presents a full- sample regression, the second uses a sub-sample with country fixed effects, and the third uses a subsample with franchisor fixed effects. The country fixed effects regression uses only 114 observations because 7 observations are the sole observation for a country, and 21 observations are from seven countries with only surviving ventures or only nonsurviving ventures. The franchisor fixed effects regression uses 91 observations because 21 franchisors only have one observation in the sample, and 30 observations are from 11 franchisors with only surviving ventures or only nonsurviving ventures. The final two columns present results of a multinomial logit regression that analyzes the likelihood of survival relative to two types of exit: exit after some units are built and subsequently closed and exit after the contract is signed but no units are built.

As shown in Table IV, the size of the development commitment is consistently negatively related to the probability of survival. This result is robust to the inclusion of country or franchisor effects. The multinomial analysis in the last two columns shows that development commitment size is negatively related to survival relative to both types of exit: exit after the franchisee built and shut down units and exit before any units were built. This latter analysis is important because it shows that large development commitments affect not only the relatively inexpensive exits where no investments in operations were ever made, but also the more economically important case where operations are built up and shut down.

Although the statistical insignificance of franchisor and country characteristics in predicting venture survival is surprising, it has a precedent. In Azoulay and Shane's (2001) study of franchisor survival, the only significant variable was also a contractual term: whether the franchisor offered exclusive territories.

To confirm that the statistically significant effect of development commitment size on survival is economically meaningful, I used the coefficients from the first column of Table IV to estimate the probabilities of survival for hypothetical ventures. All variables were held at their means other than the development commitment size variable. With a development commitment size at the 25 th percentile of those in the data ( $\$ 8.2$ million), the probability of survival is $49 \%$. With a commitment size at the 50th percentile ( $\$ 19.6$ million), the probability goes down to $42 \%$, and further decreases to $33 \%$ with a development commitment at the $75^{\text {th }}$ percentile ( $\$ 40$ million). I conclude that the development commitment size has an economically meaningful effect on the likelihood that master franchisees are still operating their ventures at the end of the development period.

\subsection{Results of the Tobit Analyses}

Table $V$ presents the results of six tobit regressions. In the first three, the dependent variable is the dollar-normalized amount invested by the franchisee in operations still functioning at the end of the development period. The development commitment size variable has a negative and significant coefficient indicating that the larger the development commitment size, the smaller the expected level of investment still productive. Because fixed effects are not appropriate for a tobit analysis, I include regressions with country and franchisor random effects. Only for the country random effects regression does significance disappear but the result remains very close to significant ( $p<0.12$ using the conservative two-tailed test). In the final three regressions, the dependent variable is the level of investment still productive at the end of the development period as a proportion of the investment specified by the initial development commitment. The development commitment size variable exhibits a consistently negative and significant effect on this proportion.

\subsection{ROBUSTNESS TESTS}

I conducted four sets of robustness tests. First, I investigated the possibility that outliers with very large development commitments are driving the results. The regression with franchisor-specific fixed effects in the third column of Table IV addresses this issue to some degree. I had to omit five of the six observations with the largest commitments from this regression because the associated franchisors only had one contract in the sample. To further evaluate the role of outliers, I estimatedregressions without the 12 observations that had commitments greater than one standard deviation above the mean. Significance remained for the equivalent of columns 1, 2, 4 and 5 in Table IV. These results suggest that outliers are not the source of the negative relationship between survival and commitment size. Among the tobit analyses presented in Table $V$, the regressions with the proportional dependent variable (columns 4-6) were robust to this exclusion of the large development commitments. In the regressions using the dependent variable of dollar- normalized productive investment (columns 1-3), the effect of the commitment variable became insignificant when the 12 largest commitments were removed. 


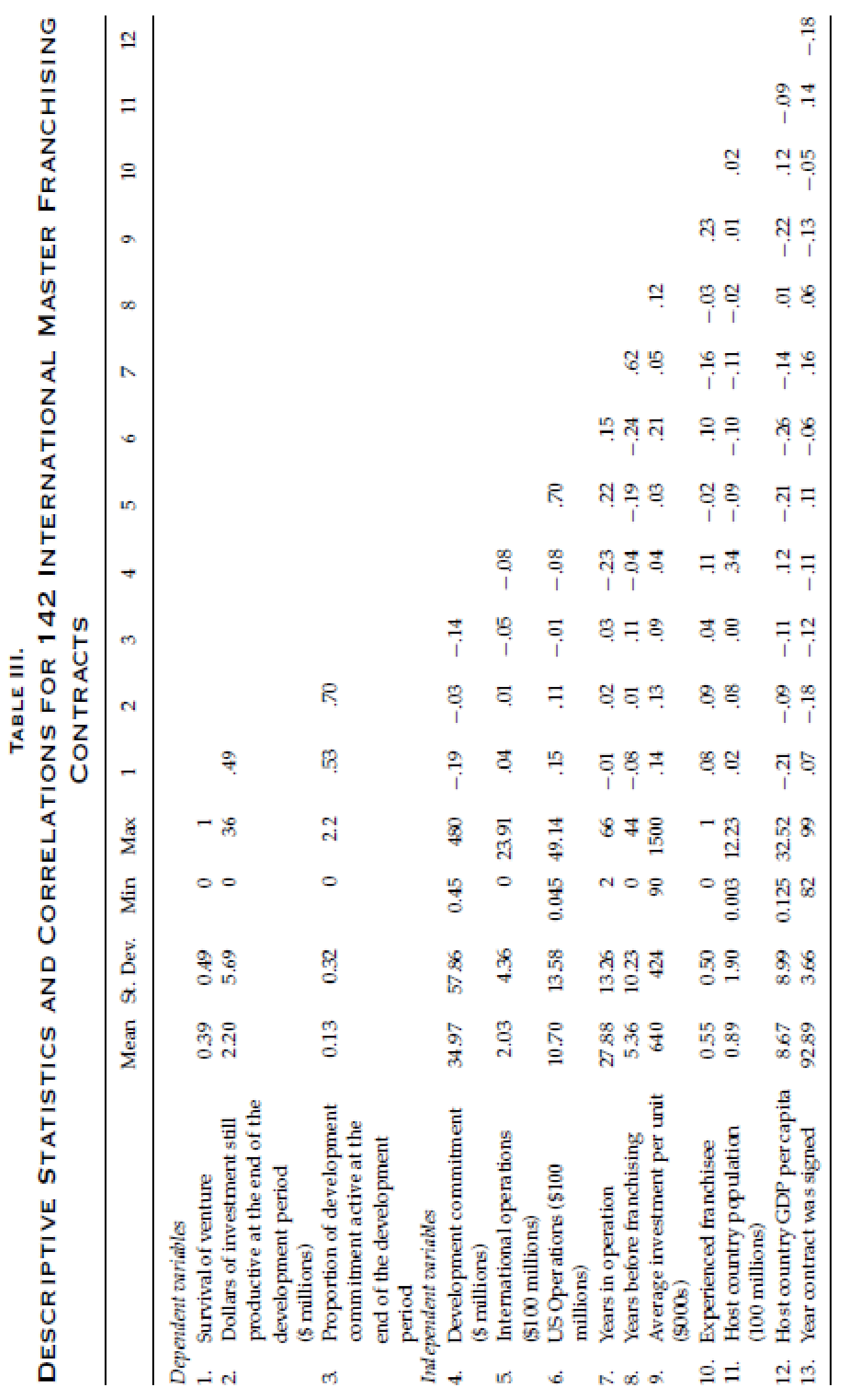


TABLE IV.

LOGIT REGRESSIONS PREDICTING SURVIVAL OF

INTERNATIONAL MASTER FRANCHISING VENTURES

\begin{tabular}{|c|c|c|c|c|c|}
\hline \multirow[b]{2}{*}{$\begin{array}{l}\text { Independent } \\
\text { Variables }^{\mathrm{a}}\end{array}$} & \multicolumn{3}{|c|}{$\begin{array}{l}\text { Binary Logit Positive } \\
\text { Coefficients: Greater } \\
\text { Likelihood of Survival }\end{array}$} & \multicolumn{2}{|c|}{$\begin{array}{l}\text { Multinomial Logit } \\
\text { Positive Coefficients: } \\
\text { Greater Likelihood } \\
\text { of Survival Relative } \\
\text { to Two Types of Exit }\end{array}$} \\
\hline & $\begin{array}{c}\text { Full } \\
\text { Sample }\end{array}$ & $\begin{array}{l}22 \text { Country } \\
\text { Fixed } \\
\text { Effects }^{b}\end{array}$ & $\begin{array}{l}18 \text { Franchisor } \\
\text { Fixed } \\
\text { Effects }\end{array}$ & $\begin{array}{l}\text { Exit after } \\
\text { Some Units } \\
\text { Built }\end{array}$ & $\begin{array}{l}\text { Exit Before } \\
\text { Any Units } \\
\text { Built }\end{array}$ \\
\hline $\begin{array}{l}\text { Development } \\
\text { commitment }\end{array}$ & $\begin{array}{r}-0.016^{*} \\
(0.008)\end{array}$ & $\begin{array}{c}-0.019^{+} \\
(0.010)\end{array}$ & $\begin{array}{c}-0.025^{+} \\
(0.014)\end{array}$ & $\begin{array}{c}-0.016^{+} \\
(0.009)\end{array}$ & $\begin{array}{r}-0.017^{*} \\
(0.009)\end{array}$ \\
\hline $\begin{array}{l}\text { International } \\
\text { operations }\end{array}$ & $\begin{array}{r}-0.073 \\
(0.067)\end{array}$ & $\begin{array}{c}-0.069 \\
(0.088)\end{array}$ & & $\begin{array}{c}-0.317 \\
(0.198)\end{array}$ & $\begin{array}{r}-0.059 \\
(0.067)\end{array}$ \\
\hline US operations & $\begin{array}{c}0.028 \\
(0.021)\end{array}$ & $\begin{array}{c}0.035 \\
(0.030)\end{array}$ & & $\begin{array}{r}0.295^{*} \\
(0.123)\end{array}$ & $\begin{array}{c}0.015 \\
(0.022)\end{array}$ \\
\hline Years in operation & $\begin{array}{c}-0.004 \\
(0.021)\end{array}$ & $\begin{array}{l}0.029 \\
(0.029)\end{array}$ & & $\begin{array}{c}-0.004 \\
(0.033)\end{array}$ & $\begin{array}{r}-0.010 \\
(0.022)\end{array}$ \\
\hline $\begin{array}{l}\text { Years before } \\
\text { franchising }\end{array}$ & $\begin{array}{c}-0.015 \\
(0.028)\end{array}$ & $\begin{array}{c}-0.054 \\
(0.036)\end{array}$ & & $\begin{array}{l}-0.026 \\
(0.040)\end{array}$ & $\begin{array}{c}-0.008 \\
(0.030)\end{array}$ \\
\hline $\begin{array}{l}\text { Avg. investment } \\
\text { per unit }\end{array}$ & $\begin{array}{c}0.001 \\
(0.000)\end{array}$ & $\begin{array}{c}0.001 \\
(0.001)\end{array}$ & & $\begin{array}{c}0.001 \\
(0.001)\end{array}$ & $\begin{array}{c}0.000 \\
(0.001)\end{array}$ \\
\hline $\begin{array}{l}\text { Experienced } \\
\text { franchisee }\end{array}$ & $\begin{array}{c}0.423 \\
(0.402)\end{array}$ & $\begin{array}{c}0.255 \\
(0.527)\end{array}$ & $\begin{array}{c}0.238 \\
(0.522)\end{array}$ & $\begin{array}{c}-0.328 \\
(0.643)\end{array}$ & $\begin{array}{c}0.535 \\
(0.424)\end{array}$ \\
\hline $\begin{array}{l}\text { Host country } \\
\text { population }\end{array}$ & $\begin{array}{c}0.069 \\
(0.116)\end{array}$ & & $\begin{array}{c}-0.003 \\
(0.135)\end{array}$ & $\begin{array}{c}-0.096 \\
(0.136)\end{array}$ & $\begin{array}{c}0.219 \\
(0.185)\end{array}$ \\
\hline $\begin{array}{l}\text { Host country GDP } \\
\text { per capita }\end{array}$ & $\begin{array}{l}-0.041 \\
(0.025)\end{array}$ & & $\begin{array}{c}-0.002 \\
(0.030)\end{array}$ & $\begin{array}{c}0.004 \\
(0.037)\end{array}$ & $\begin{array}{r}-0.053^{4} \\
(0.027)\end{array}$ \\
\hline $\begin{array}{l}\text { Year contract was } \\
\text { signed }\end{array}$ & $\begin{array}{c}0.045 \\
(0.055)\end{array}$ & $\begin{array}{c}0.072 \\
(0.070)\end{array}$ & $\begin{array}{c}0.013 \\
(0.088)\end{array}$ & $\begin{array}{c}0.101 \\
(0.089)\end{array}$ & $\begin{array}{c}0.040 \\
(0.057)\end{array}$ \\
\hline $\begin{array}{l}\text { Number of } \\
\text { observations }\end{array}$ & 142 & 114 & 91 & 142 & \\
\hline $\begin{array}{l}\text { Number of } \\
\text { survivors }\end{array}$ & 55 & 47 & 48 & -5 & \\
\hline Number of exits & 87 & 67 & 43 & 66 & 21 \\
\hline Log likelihood & -84.4 & -37.5 & -34.9 & -121.9 & \\
\hline
\end{tabular}

ip < 0.05; ${ }^{+} p<0.10 ;$ two-tailed tests "I estimated additional regressions with variables not included here. These include a split of the franchisor's "US operations" into company-owned and iranchised operations, percentage of US operations that are company-owned, and dummies for nonnative franchisees and franchiseses that are existing firms vs. individuals. None of these variables vielded any significant results, nor did they change any significance levels of the development commitment variable. The Chamberlain model is used when fixed effects are included. I had to remove 28 observations from the country fixed efferts negression because the ventures are from countries with no within-country variation regarding survival.

had to remove 51 observations from the franchisor fived effects regreasion for the same reason

Second, I replaced the dollar-normalized "development commitment" and "investment in operations" variables with nonnormalized counts of units. Regressions equivalent to those in Table IV with these nonnormalized variables yield the same levels of significance for the commitment variable with the exception of the franchisor fixed effects regression. Just like in the normalized case, significance remains when all observations with development commitments greater than one standard deviation above the mean are dropped. When the nonnormalized commitment variable is used in the tobit regressions in the first three columns of Table $V$, the coefficients are not statistically significant, but this is to be expected. If no normalization takes place based on investment per unit, the tobit specification is biased in favor of a positive relationship between the development commitment and the number of units still operating at the end of the development commitment period. Chains that have inexpensive units will naturally have higher numbers of both, leading to a misleading appearance of a positive relationship.

Third, I estimated regressions with only the 84 observations where an explicit development commitment period was stated in the announcement. Coefficients for the development commitment variable were negative and significant both in the logit regressions in columns 1, 3, 4, and 5 of Table IV and in all six tobit regressions in Table V. For the 58 ventures without an explicitly stated period, I investigated alternatives to the 5 -year cutoff. I estimated a "predicted period" based on development commitment size, because these two variables are correlated at 0.44 for the 84 observations with an explicit period. For the 58 observations, assessing survival at the end of the predicted period relative to using the 5 -year cutoff did not yield a single change from survivor to nonsurvivor or vice versa. However, I had to remove two observations because their predicted periods extend beyond 2004. Both the logit and tobit results using the full sample minus two observations remained at similar levels of significance to those reported in Tables IV and V. I conclude that my main results are not driven by the subsample without a stated commitment period or by the 5 -year assumption that I applied to the subsample.

Fourth, I estimated regressions with additional variables not shown. These include separate company-owned and franchised US operations variables, percentage of US operations company-owned, percentage of total operations that are international, growth rate of the franchisor domestically and internationally, and dummies for nonnative franchisees and franchisees that are existing firms versus individuals. None of these variables yielded any significant results nor did they change significance levels of the development commitment variable.

\section{DISCUSSION}

\subsection{Why Franchisors May Demand Development Commitments that are too large}

I briefly discuss four reasons-bounded rationality, cognitive biases, power seeking, and opportunism - why some franchisors may insist on development commitments that are too large. First, some boundedly rational franchisors will overestimate the potential of new markets, while others will underestimate market potential. The overestimating franchisors are likely to insist on development commitments that are too large because of their desire for a high level of market development.

Second, franchisors may insist on large development commitments because they are subject to decision-making biases and, again, desire full market development. Caves (1998) argued that a firm's level of confidence in a new venture is reflected in the venture's initial size, implying that an initial estimate such as a development commitment also captures confidence. Confidence may be an unbiased reflection of actual ability, but it may also be systematically unrealistic. The findings that individuals are overconfident in their abilities (e.g., Camerer and Lovallo, 1999) and overoptimistic about their environment (March and Shapira, 
Third, franchisors may insist on large development commitments to gain bargaining power over their master franchisees. Franchisors could possibly threaten to enforce a development commitment any time a master franchisee engages in activities frowned upon by the franchisor, but that the franchisor could not stop so easily legally. An example of such an activity is the case mentioned earlier where a master franchisee starts to build nonbranded units similar in appearance to those of the franchisor's brand.

Fourth, fledgling franchisors may opportunistically overstate market potential and insist on large development commitments to appear more similar to their larger and more experienced competitors. This appearance of similarity may bring the franchisors legitimacy that allows them to procure resources from financial institutions and potential franchisees (e.g., Meyer and Rowan, 1977; Langevoort, 1997). This argument implicitly assumes biases on the part of the resource-providing institutions because they are unable to discount the unrealistic claims made by legitimacy-seeking actors.

\subsection{Why franchisees May Accept Development Commitments that are too large}

Regardless of why franchisors insist on large development commitments, rational franchisees will prefer a minimal development commitment because they incur most of the costs related to the venture. Nonetheless, franchisees may agree to a very large commitment due to overconfidence in either their abilities or their estimation accuracy, or because they may view it as an acceptable risk-return trade-off.

Overconfidence in estimation accuracy may manifest itself as a winner's curse in cases where franchisors accept multiple bids for a master franchise. The franchisee that overestimates market potential the most is likely to agree to the largest commitment and win the master license. I note that overconfidence in estimation accuracy greatly facilitates the emergence of a winner's curse because rational bidders would adjust their bids downward from their initial valuation to take the curse into account (Kagel and Levin, 1986; Thaler, 1992, p. 51).

Large development commitments might be associated with ventures that are high in risk but also high in return. Although rational franchisees would prefer no development commitment at all ceteris paribus, they may accept a large commitment as long as they are somehow compensated for the additional risk. Any risk and return variation among the ventures in these data may be the result of country or franchisor characteristics. Or, in the spirit of recent models such as Szalay (2005), some franchisors may be endogenously creating a high-risk- high-return venture by insisting on large commitments and refusing to renegotiate. Such behavior may be optimal from the franchisor's point of view to the extent that it forces the franchisee to invest heavily in information acquisition. However, the fact that 49 of 55 surviving ventures appear to have been renegotiated explicitly or implicitly casts doubt on any line of reasoning dependent on a commitment not to renegotiate.

\subsection{Causal explanations for the Development Commitment-Survival Relationship}

A too-large development commitment size alone is unlikely to have a negative causal effect on venture survival if (1) the commitment can be easily renegotiated and (2) if there are no ongoing effects of biased decision making. If new information indicates that the original commitment size is infeasible, the master franchisee as well as the franchisor should be willing to negotiate a new, smaller commitment to facilitate venture survival. ${ }^{3}$ Even if a franchisee has incurred set-up costs due to a large commitment, they should be able to write these off as sunk costs and revert to a cost structure and strategy used by franchisees operating at a smaller scale in the same market. Thus, they should have an equal likelihood of survival as those franchisees that did not initially agree to a large development commitment.

Of course, the franchisor may incur fewer costs by revoking the master license and terminating the venture rather than renegotiating the commitment. However, I discount costly renegotiation as a causal explanation for the association of large commitments and low survival rates. Of the 55 surviving ventures, franchisors and franchisees appear to have renegotiated 49 ventures because these 49 never fulfilled the development commitment. Further, franchisors terminated only five of the 87 nonsurviving ventures in commitment-related lawsuits indicating that franchisors rarely terminate a functioning venture.

Initial overestimates of feasible development commitment size may be causally associated with lower survival rates due to ongoing effects of biased decision making. In particular, Tversky and Kahneman (1974) found that initial estimates such those reflected in a development commitment act as an "anchor," and subsequent adjustments made in light of new information will be smaller than optimal. ${ }^{4}$ For this reason, an initial overestimate may be causally related to an ongoing insistence to fulfill more of the commitment than is optimal. Because managerial effort is likely convex in cost in each time period, and because franchisees gain option value by not developing many units at once (Lafontaine and Leibsohn, 2004), managers may misallocate effort away from more productive tasks to develop too many new units. Eventually, survival of the venture may be jeopardized. Unlike the costly renegotiation argument, the logic that managerial biases lower the likelihood of survival does not require enforceability of the commitments. Even as an unenforceable motivational goal, the commitment may act as an anchor that franchisees take into account inappropriately when making resource allocation decisions.

\subsection{Selection-Based Explanations for the Development Commitment Size-Survival Relationship}

Alternatively, two types of selection may explain the commitment size-survival relationship. First, unobservable franchisee attributes may provide an explanation. In particular, a franchisee with a consistent propensity toward overconfidence or overoptimism may select a large development commitment and may also be unlikely to survive. Thus I conclude that franchisee biases could yield the data patterns found here either causally, as discussed in the previous section, or via selection. The commitment size-survival relationship is not likely the result of selection based on unobservable franchisor attributes because the relationship remains in the presence of franchisor fixed effects.

Second, franchisors and franchisees may select large development commitments for ventures that are high in risk and high in return. The high risk may well translate into low probabilities of survival. I discount this explanation because the surviving ventures should enjoy high returns. High returns are very unlikely without a high level of investment still productive at the end of the commitment period. This logical conclusion contradicts the empirical results in Table V. Further, to the extent that variations in risk and return are driven by country or franchisor characteristics, the fixed effects regressions in Table IV remove any such effects from the coefficient of the development commitment variable.

\subsection{Other Plausible Reasons for Signing Contracts with large development Commitments}

At least two other plausible motivations exist for franchisors to insist on, and franchisees to accept, large development commitments: quality signaling and preemption. First, in the spirit of models of Gallini and Lutz (1992) and Dessein (2005), respectively, franchisors may use large commitments to yield an equilibrium

\footnotetext{
3 The franchisor could insist on additional concessions from the franchisee in exchange for the reduction in the development commitment. Concessions such as higher fees or royalties could plausibly reduce the

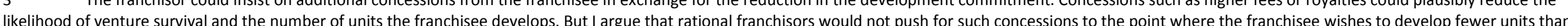
they would have under the initial terms. Higher royalties would only exacerbate the double marginalization and "knock-off" problems discussed in Section 2.3. Overconfident or overoptimistic franchisors might behave they would hav 4 differently. curse in the first place.
} 
that separates franchisees based on quality or based on congruence of objectives with the franchisor. Second, franchisors may use large development commitments to preempt competition. However, models such as Dixit (1980) require actual investment, rather than a mere announcement, to make preemption credible. I further discount these explanations because, to the extent that the signaling or preemption function is intended, they should not cause lower survival rates and a lower level of investment still productive at the end of the commitment period.

\section{CONCLUSIONS}

In this paper, I have made two contributions. First, I presented several intriguing empirical regularities based on a sample of 142 international master franchising contract announcements. Of the ventures associated with these contracts, 87 (61\%) did not survive to the end of their development commitment period. Further, surviving ventures typically came nowhere near to building the number of units specified by the development commitments. Only 6 of the 55 ventures still ongoing at the end of their development periods fulfilled or exceeded the commitment size. Finally, among the 87 nonsurvivors, only 5 were accompanied by news of lawsuits regarding nonfulfillment of the commitments. These findings suggest that franchisors and franchisees initially overestimate the potential of markets, but are willing to formally or informally renegotiate international master franchising contracts.

Although the $39 \%$ survival rate for international master franchising ventures found here appears low, it is consistent with academic work on foreign direct investment (e.g., Mitchell et al., 1994). Further, the franchisee investments studied here may well be profitable on average. The fact that surviving ventures yielded 806 functioning units built with an investment of $\$ 285$ million, while the nonsurviving ventures yielded at least 407 closed units (\$189 million), may well imply a positive NPV for each franchisee ex ante at an acceptable discount rate, and a net welfare gain for the host countries.

The second contribution of this paper is the presentation of empirical evidence that large development commitment size is associated with a lower probability of venture survival and a lower level of investment still productive at the end of the development period. The survival result is robust to the inclusion of country and franchisor fixed effects, the removal of outliers (contracts with commitments more than one standard deviation above the mean), and specification of the development commitment size variable in terms of dollars or units. A multinomial logit analysis shows that large development commitment size is significantly associated with venture exit not only before any units are built but also in the more economically meaningful case where some units were built but shut down.

Based on these findings, I conclude that large development commitments are more likely the result of overestimation by franchisees than the result of a risk-return trade-off. A risk-return argument implies that, contrary to the results here, some ventures should have a surviving investment large enough to yield a payoff that outweighs the lower survival rate. I was also able to discount signaling and preemption explanations for the large development commitments. If these explanations were to generate any relationship between commitment size and survival, it would likely be a positive one.

Although an archival study of commitments such as this one cannot decisively pinpoint specific behavioral sources of systematic overestimation, evidence suggestive of overestimation such as that presented here is nonetheless valuable. While empirical studies of foreign market entry are legion, few have evaluated the possibility of overestimation and its possible ramifications. ${ }^{5}$ Hopefully this study will serve as an encouragement for future work to more definitively determine the sources and implications of overestimation in collaborative market entry.

\section{REFERENCES}

Anand, B. and T. Khanna, 2000, "The Structure of Licensing Contracts," Journal of Industrial Economics, 48,103-135.

Azoulay, P. and S. Shane, 2001, "Entrepreneurs, Contracts, and the Failure of Young Firms,"

Management Science, 47,337-358.

Bond, Robert, 1985-1999, Bond's Franchise Guide, 1st-10th eds. Oakland, CA: Sourcebook Publications.

Brickley, J. and F. Dark, 1987, "The Choice of Organizational Form: The Case of Franchising," Journal of Financial Economics, 18, 401-420.

Bygrave, W., 1999, The Portable MBA in Entrepreneurship, 2nd ed., New York: Wiley.

Camerer, C. and D. Lovallo, 1999, "Overconfidence and Excess Entry: An Experimental Approach," American Economic Review, 89,306-318.

Caves, R., 1996, Multinational Enterprise and Economic Analysis, 2nd ed., Cambridge, UK: Cambridge University Press.

-------, 1998, "Industrial Organization and New Findings on the Turnover and Mobility of

Firms," Journal of Economic Literature, 36,1947-1982.

------- and W. Murphy, 1976, "Franchising: Firms, markets and intangible assets," Southern

Economic Journal, 42, 572-586.

Chaudhry, R., 1991, "Room to Grow in Japan," Restaurants and Institutions, January 9,108.

Coval, J. and T. Shumway, 2005, "Do Behavioral Biases Affect Prices?," Journal of Finance, 60,1-34.

Daniel, K., D. Hirshleifer, and A. Subrahmanyam, 1998, "Investor Psychology and Security Market Under- and Over-Reactions," Journal of Finance, 53,1839-1885.

Dessein, W., 2005, "Information and Control in Ventures and Alliances," Journal of Finance, forthcoming.

Dixit, A., 1980, "The Role of Investment in Entry Deterrence," Economic Journal, 90,95-106.

Dixon, E., 1987-1999, The Franchise Annual, 18th-30th eds, Various Presses.

Estes, G., 1995, "Having it Their Way: Burger King enters Chilean Market," Latin American Law and Business Report, Vol. 3, No. 6

Gallini, N. and N. Lutz, 1992, "Dual Distribution and Royalty Fees in Franchising," Journal of Law, Economics, and Organization, 8(3), 471-501.

Greene, W., 2000, Econometric Analysis, 4th ed., Upper Saddle River, NJ: Prentice-Hall.

Kaufmann, P. and V. Rangan, 1990, "A Model for Managing System Conflict During Franchise Expansion". Journal of Retailing, 66(2): 155-173.

Kagel, J. and D. Levin, 1986, "The Winner's Curse and Public Information in Common Value Auctions," American Economic Review, 76, 894-920.

Lafontaine, F. and D. Leibsohn, 2004, Beyond Entry: Examining McDonald's Expansion in International Markets, Mimeo, University of Michigan.

and J. Oxley, 2004, "International Franchising: Evidence from US and Canadian

5 See Caves (1996) for an exhaustive survey of the literature on foreign market entry. Existing empirical studies on managerial biases in economic settings have investigated investor behavior (e.g., Odean, 1999, Covel and Shumway, 2005), CEO financing decisions (Malmendier and Tate, 2004), and entrepreneurs' preference for short-term debt (Landier and Thesmar, 2004). 
Franchisors in Mexico, Journal of Economics and Management Strategy, 13, 95-123.

Landier, A. and D. Thesmar, 2004, Financial Contracting with Optimistic Entrepreneurs, Mimeo, University of Chicago.

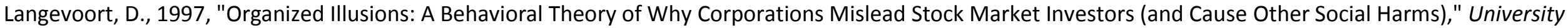
of Pennsylvania Law Review, 146(1), 101-172.

Malmendier, U. and G. Tate, 2004, "Who Makes Acquisitions? CEO Overconfidence and the Market's Reaction," Journal of Finance, forthcoming.

March, J. and Z. Shapira, 1987, "Managerial Perspectives on Risk and Risk Taking," Management Science, 33,1404-1418.

Meyer, J. and B. Rowan, 1977, "Institutionalized Organizations: Formal Structure as Myth and Ceremony," American Journal of Sociology, 83, $340-363$.

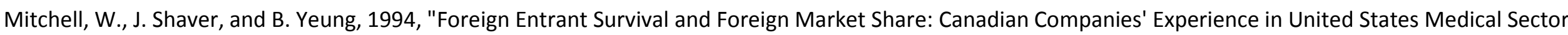
Markets," Strategic Management Journal, 15, 555-567.

Odean, T., 1999, "Do Investors Trade Too Much?," American Economic Review, 89, 12791298.

Read, R., 1991, "Business Cookin' at Japanese Spaghetti Franchisees," Portland Oregonian, October 13: M1

Szalay, D., 2005. "The Economics of Extreme Options and Clear Advice," Review of Economic Studies, forthcoming.

Thaler, R., 1992, The Winner's Curse, Princeton, NJ: Princeton University Press.

Tversky, A., D. Kahneman, 1974, "Judgment under Uncertainty: Heuristics," Science, 185, 1124-1131.

Walker, B., 1989, A Comparison of International vs. Domestic Expansion by US Franchise Systems, Washington, DC: International Franchise Association

Zietlow, D. and J. Hennart, 1996, "The International Distribution of Franchises by US Franchisors," Working Paper 96-102, University of Illinois Center for International Business Education. 